\title{
Population dynamics and life cycle of Pisidium amnicum (Müller) (Bivalvia : Sphaeriidae) and Valvata piscinalis (Müller) (Gastropoda : Prosobranchia) in the Saône river, a nine-year study
}

\author{
J. Mouthon ${ }^{1} \&$ M. Daufresne ${ }^{2}$ \\ ${ }^{1}$ Cemagref, DSA, 3 bis quai Chauveau, CP 220, F-69336 Lyon cedex 09, France. \\ ${ }^{2}$ Cemagref, UR Hydrobiologie - Equipe Ecosystèmes Lacustres, 3275 Route de Cézanne, CS 40061, F-13182 Aix-en-Provence \\ Cedex 5, France.
}

The population dynamics and life cycle of two mollusc species Pisidium amnicum and Valvata piscinalis of the Saône river were studied for nine years. The newborn of the former species appeared in April each year. The latter species produced two cohorts per year until 2003. Spawning in spring led to the birth of the early cohort, which generally appeared in May, while spawning in the summer led to the birth of the late cohort, which appeared from July to November. The increase of the mean annual temperature by $1.9^{\circ} \mathrm{C}$ from 1998 to 2000 was followed by an increase in the density of mollusc populations, possibly triggering or amplifying inter and intra specific competition for food. However, the 2003 heatwave was responsible for the sudden decline of the $P$. amnicum population, then the more progressive decline of that of $V$. piscinalis after having strongly modified its demographic structure and its life cycle. In 2004 and $2005 \mathrm{~V}$. piscinalis only produced one cohort per year. The observations carried out strongly suggest that the insufficiency of available resources was one of the possible causes of their failure to recover in 2004 and 2005 . The increase of global warming predicted by different models could result in the gradual disappearance of $P$. amnicum from the potamon and of $V$. piscinalis from the freshwater systems most directly exposed to climatic warming, such as the Saône River.

Keywords: Pisidium, Valvata, population dynamics, life cycle, heatwave

\section{Introduction}

Since the second half of the 19th century, the global mean temperature has increased by $0.95^{\circ} \mathrm{C}$ in Europe (EEA 2004), and 2003 was probably the hottest year since at least 1500 (Black et al. 2004, Luterbacher et al. 2004). At the macroinvertebrate community level of freshwater systems, the ecological consequences of global warming are manifested by gradual changes in structure and species composition, with extreme climatic events causing the most considerable effects such as a significant decrease of species richness and density (Bradley \& Ormerod 2001, Daufresne et al. 2004, 2007, Mouthon \& Daufresne 2006, Burgmer et al. 2007). Furthermore, at organism level the impact of climate affects the physiological processes, population dynamics and competitive interactions (Stenseth et al.

\footnotetext{
* Corresponding author : E-mail : jacques.mouthon@ cemagref.fr
}

2002, Walther et al. 2002). In the Saône river the mean annual temperature increased by $2.6^{\circ} \mathrm{C}$ from 1996 to 2003 (Mouthon \& Daufresne, 2006), thus major modifications of the population dynamics of molluscs must have occurred during this period. In order to verify this hypothesis two species were chosen: the bivalve Pisidium amnicum (Müller), the largest species of the genus whose size usually ranged from 7 to $11 \mathrm{~mm}$, and the gastropod Valvata piscinalis (Müller), a dominant species of this river.

The former inhabits the fine deposits of rivers and lakes of lowland regions. It is hermaphroditic, capable of self-fertilization and ovoviviparous. The young develop inside the marsupium or brood sac on the inner demibranches of the gills and only one developmental stage can be observed at any one time. (Odhner 1929, Thomas 1959, Heard 1965, Meier-Brook 1970, Mackie 1978). The latter is a more common species that inhabits a large variety of freshwater systems. It is hermaphroditic and its eggs are laid in gelatinous capsules gener- 
ally fixed on macrophytes and more rarely on stones. Each individual can lay 10 capsules (Frömming 1956), each of which can contain from 5 to 60 eggs (Nekrassov 1929). P. amnicum is an interstitial suspension feeder (Lopez \& Holopainen 1987) and V. piscinalis a detritus feeder (Fretter \& Graham 1978), but it can also feed by filtration on detritus in mud (Tsikhon-Lukanina 1963). These two molluscs are generally considered as annual species (Cleland 1954, Hunter 1961, Young 1975, Danneel \& Hinz 1976, Bass 1979, Holopainen 1979, Vincent et al. 1981, Holopainen et al. 1997, Araujo et al. 1999), however the appearance of a second generation was observed in $V$. piscinalis in response to a considerable decrease of its population due to a dramatic decline of submersed macrophytes (Lodge \& Kelly 1985). Regarding biodegradable pollution, $P$. amnicum is sensitive while $V$. piscinalis is relatively tolerant (Mouthon 1996). The aim of this article is to highlight and then describe the possible consequences (direct and/or indirect effects) of the warming of the waters of the Saône river on the population dynamics, life cycle and history traits of these two species over a period of 9 years.

\section{Materials and methods}

Mollusc samples were collected monthly (generally during the third week) from September 1996 to December 2005 in the Saône upstream of the Ile Barbe, at the river's entry in the conurbation of Lyon. More details about the sampling site, i.e. geographical situation, description, temperature and discharge data were presented in Mouthon (2001, 2004, 2007) and Mouthon \& Daufresne (2006). Sampling was carried out using a rectangular hand-net ( $25 \times 18 \mathrm{~cm}, 315 \mu \mathrm{m}$ mesh), sampling a total area of $0.25 \mathrm{~m}^{2}$ at every station. Four stations varying in depth from 0.50 to $1.5 \mathrm{~m}$ were sampled. Sampling was not possible during flood periods. These samples were kept separately and fixed on-site in $12 \%$ neutralised formaldehyde and then sieved at $315 \mu \mathrm{m}$ in the laboratory, where the molluscs were separated from the sediment and identified. Density was calculated based on the average of these four stations.

The shell length (SL, largest anterior-posterior dimension across the valves) of $P$. amnicum was measured with an eye piece micrometer at $25 \mathrm{x}$ (bivalves with $\mathrm{SH}<6.0 \mathrm{~mm}$ ) or $12.5 \mathrm{x}$ (bivalves with $\mathrm{SH}>6.0$ ) under a binocular microscope, and assigned to size classes of $0.5 \mathrm{~mm}$ width. When the number of $V$. piscinalis sampled was high ( $>150$ ind. $\left.\mathrm{m}^{-2}\right)$, individuals of infrequent size classes were set aside, after which a subsample (ranging between 0.05 and 0.5 ; always representing at least 100 individuals) of the other gastropods was taken randomly. The maximum diameter (MD) i.e. the greatest transverse width (Hunter 1961) of the individuals set aside and of those selected was measured with an eye piece micrometer at $25 \mathrm{x}$ under a binocular microscope, and assigned to size classes of $0.5 \mathrm{~mm}$ width.

The resulting histograms were analysed using Bhattacharya's (1967) graphical method available in the FiSAT software distributed by FAO-ICLARM (Gayanilo et al. 1996), which allows separating each lengthfrequency distribution into Gaussian components. For each cohort, the mean size of the individuals, the number and the standard deviation were established.

All the bivalves measured were dissected to establish the number of larvae in the marsupium and the number of infested individuals by digenean trematodes. The larvae were separated into two size classes: $<$ and $>1$ $\mathrm{mm}$. Only larvae with SL close to $1 \mathrm{~mm}$ were effectively measured whereas the smaller or longer ones were assigned to one or the other size class.

To establish the number of gravid individuals and those infested by digenean trematodes, 30 gastropods (with $\mathrm{MD}>2$ ) $\mathrm{mm}$ were taken randomly each month when possible and then dissected. $V$. piscinalis are gravid when ripe ova form bulges on the outer wall of the hermaphrodite gland (Cleland 1954). The statistical analyses used (ANOVAs, linear regression and Tukey's HSD post-hoc tests) were extracted from the Statistica package library (version 7.0).

\section{Results}

\section{Density variations}

We observed significant variations in the mean annual densities of the $P$. amnicum and $V$. piscinalis populations during the study period (ANOVA, $\mathrm{p}<0.01$ and $\mathrm{p}<0.05$, respectively - Fig $1 \mathrm{a} \& \mathrm{~b}$ ). Between the periods 1997-1999 and 2000-2002 the density of P. amnicum increased significantly (Tukey's HSD test $\mathrm{p}<0.01$ ). In 2000 it reached a maximum of 81.5 ind. $\mathrm{m}^{-2}$. In 2003 it returned to a level comparable to that of 1997 and 1998 (28.6 ind. $\left.\mathrm{m}^{-2}\right)$ then declined rapidly in 2004 (2.1 ind. $\mathrm{m}^{-2}$ ). This density was significantly lower than the mean density in 2003 (Tukey's HSD test $\mathrm{p}<0.05$ ). In 2005 only two individuals were sampled.

From 1997 to 2001, the mean annual density of $V$. piscinalis varied from 208.3 (2001) to 441.5 ind. $\mathrm{m}^{-2}$ (1998). Between 2001 and 2002, it increased by a factor of 4 and reached a maximum of 872.7 ind. $\mathrm{m}^{-2}$, then pro- 

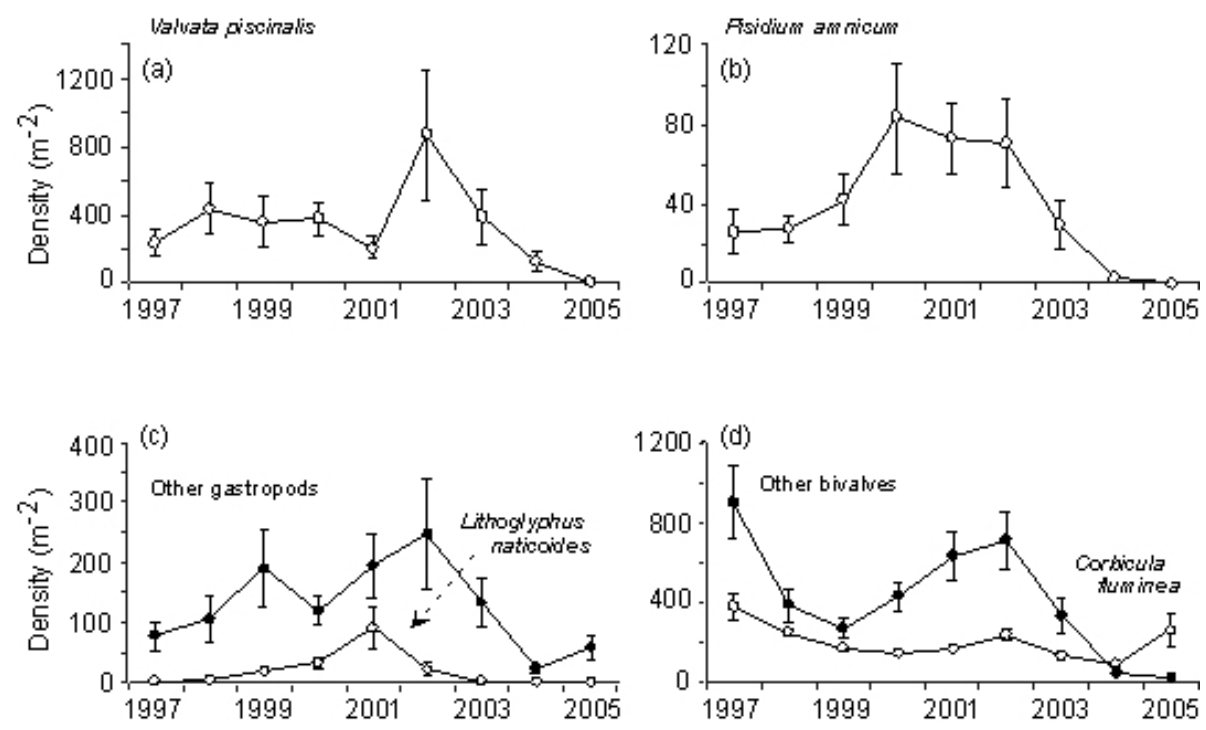

Fig. 1. Annual variations in the mean annual density populations ( \pm SE) of Pisidium amnicum (a), Valvata piscinalis (b), and of potential competitors : "Other bivalves" and Corbicula fluminea (d), "Other gastropods" and Lithoglyphus naticoides (c) of the Saône river (see discussion).

gressively decreased until 2005 when there were only 5.8 ind. $\mathrm{m}^{-2}$ (Fig. 1b). This final density, significantly lower than the mean density in 2001 (Tukey's HSD test, $\mathrm{p}<0.05$ ), was the lowest during the study period.

\section{Life cycle variations (P. amnicum)}

Adults aged 13 months and released young every year in April (Fig. 2, Table 1). The temperature of the water at this period ranges from 12 to $13.8^{\circ} \mathrm{C}$. The mean size of these newborn varies from $2.31 \mathrm{~mm}$ (1999) to $3.0 \mathrm{~mm}(2000,2002$ and 2003). They grew rapidly except in 2000, 2002 and 2003 during which the increase in cohort size only started in June or July. Eggs appeared in the inner demibranches in July and August and shelled larvae a month later. The incubation period ended in April or, more rarely, in May (2002) of the following year (Fig 3). However, the beginning of a new incubation period was regularly observed in several individuals except in 2001 and 2003 but all the adults died during the summer and these larvae failed to complete their development. The number of gravids was maximum in summer (from July to September) and that of shelled larvae in September (cohorts 1997, 1998 and 2000), November (cohorts 1999 and 2001) or January (cohort 2002) (Fig 3). Only three gravids were observed in 2003, while none were observed in 2004.
The mean litter size (mean number of shelled larvae/ parent) varied from 44.0 to 20.2 . The maximum larvae SL measured $2.36 \mathrm{~mm}$ and the minimum size of the young was $1.16 \mathrm{~mm}$. Other life cycle data are summarized in Table 1 . The $P$. amnicum population of the Saône river only produces a single cohort per year and its life span varies from 16 to 18 months.

We observed significant inter-annual variations in the mean SL of $P$. amnicum in October (ANOVA, $\mathrm{P}<0.05$ ) and in the mean litter size/cohort (ANOVA, $\mathrm{p}<0.01$ ). From 1997 to 2002 these two parameters decreased significantly: the former by $1.86 \mathrm{~mm}$ (Tukey's HSD test $\mathrm{p}<0.05$ ) and the latter by 23.8 (Tukey's HSD test p $<0.001$, Fig. 4 a \& b). However the inter-annual variability in October of the size of individuals and litter size were not significantly related to temperature during the growth (April to October) and the incubation periods, respectively (linear regressions, $\mathrm{p}$ values $>0.05$ ).

Digenean trematodes were observed in the gonads and/or the digestive gland of the bivalves. Prevalence (percentage of clams infected) varied from 2.0 to $7.7 \%$ (mean 5.8\% for the period 1997-2003). It reached its highest percentages from 2000 to 2002 when densities were highest (Table 1, Fig 1). The individuals in size classes 4-7 and 7-10 mm SL were the most infected (58.3 and $29.1 \%$, respectively). The minimal size of clams with parasites was $3.17 \mathrm{~mm}$. 


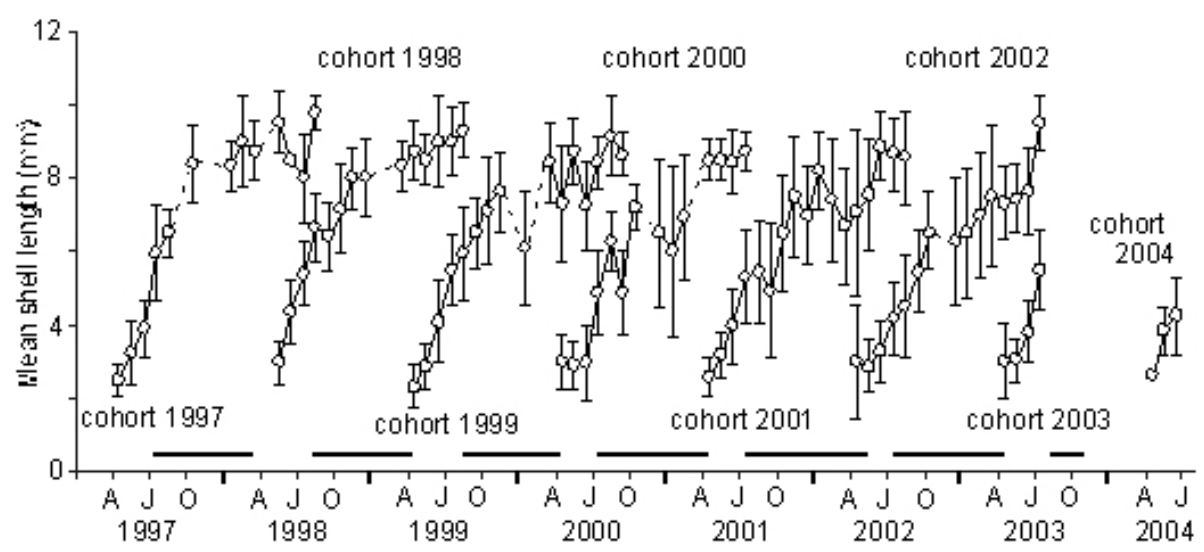

Fig. 2. Mean cohort shell lengths (open circles) in monthly samples of the Saône river Pisidium amnicum population. Vertical bars are standard deviations. The solid bars above the horizontal axis indicate periods when adult individuals were gravid. Dotted lines indicate the presumed changes in mean lengths.

Table 1. Life cycle data for Pisidium amnicum in the Saône river

\begin{tabular}{|c|c|c|c|c|c|c|c|c|}
\hline cohort & 1997 & 1998 & 1999 & 2000 & 2001 & 2002 & 2003 & 2004 \\
\hline Maximum shell length (mm) & 11.04 & 10.74 & 11.66 & 10.16 & 11.16 & 10.75 & 10.41 & - \\
\hline Mean SL in October (mm) & 8.36 & 7.19 & 7.13 & 7.29 & 6.47 & 6.49 & - & - \\
\hline Minimum mature size (mm) & 4.56 & 4.48 & 4.58 & 2.72 & 3.4 & 3.24 & 5.66 & - \\
\hline $\begin{array}{l}\text { Month at which gravid } \\
\text { individuals appear }\end{array}$ & July & August & August & July & July & July & August & - \\
\hline $\begin{array}{l}\text { Month at which the first } \\
\text { cohort appears }\end{array}$ & April & April & April & April & April & April & April & April \\
\hline Number of cohorts/year & 1 & 1 & 1 & 1 & 1 & 1 & 1 & 1 \\
\hline $\begin{array}{ll}\text { Litter size } & \\
& \text { - mean }\end{array}$ & 44.0 & 34.7 & 32.5 & 23.7 & 26.3 & 20.2 & - & - \\
\hline - maximum & 163 & 79 & 86 & 93 & 136 & 74 & 42 & - \\
\hline $\begin{array}{l}\text { Maximum length of shelled } \\
\text { larvae }(\mathrm{mm})\end{array}$ & 1.76 & 2.16 & 2.36 & 2.2 & 2.36 & 2.08 & - & - \\
\hline Prevalence/year & 2.0 & 3.7 & 2.9 & 6.6 & 7.7 & 7.3 & 4.7 & - \\
\hline $\begin{array}{l}\text { Minimal size of parasited } \\
\text { individual }(\mathrm{mm})\end{array}$ & 6.32 & 5.36 & 3.17 & 3.40 & 3.56 & 3.32 & - & - \\
\hline Life-span (months) & 16 & 16 & 18 & 16 & 17 & 16 & $4 ?$ & $3 ?$ \\
\hline
\end{tabular}




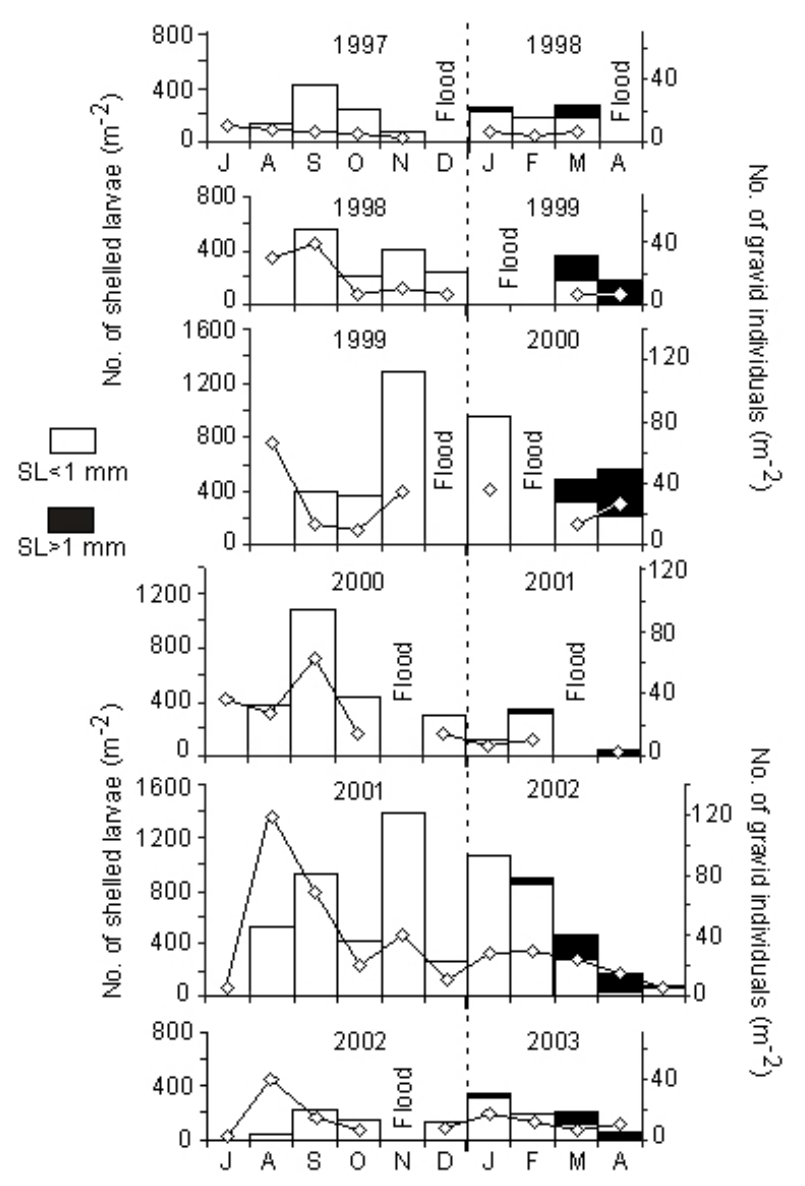

Fig. 3. Number $\mathrm{m}^{-2}$ of gravid Pisidium amnicum (open trianglesright vertical axis) and shelled larvae incubated (left vertical axis). Cohorts 1997 to 2002.

\section{Life cycle variations $(V$. piscinalis)}

From 1996 to 2003, the birth of two cohorts was observed each year, and then a single cohort was born in 2004 and 2005 (Fig. 5). The early cohort appeared in May (1997 to 2000, 2002 and 2003), the mean MD of newborn individuals being $0.5 \mathrm{~mm}$, or in June (2001, 2004 and 2005). In the latter case, the MD of the newborn $>1 \mathrm{~mm}$ suggests that the cohort was born either at the end of May (shortly after sampling), or at the beginning of June. The early cohort disappeared between June and August after having spawned. Its longevity was in the region of 13 to 15 months (Table 2).

The late cohort appeared in July (2003), August (2002), September (1997), October (1998-2000) or
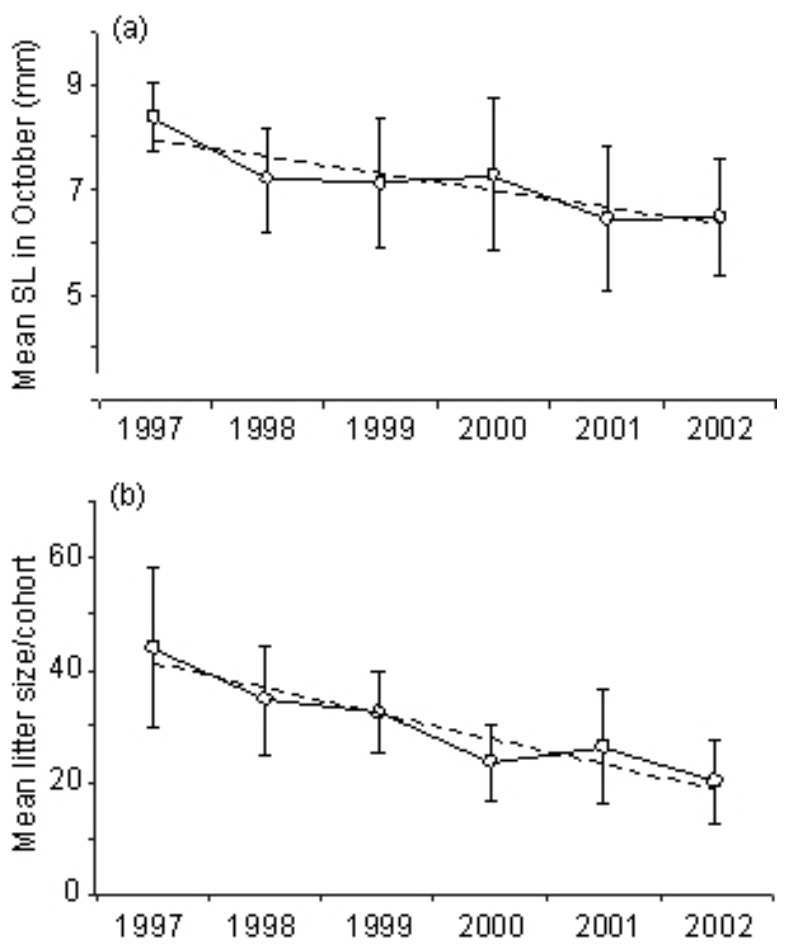

Fig. 4. (a) Variation of mean shell length in October and (b) of mean annual litter size/cohort of Pisidium amnicum. Trends are shown $(\mathrm{Y}(\mathrm{t})=\mathrm{at}+\mathrm{b})$.

November (1999-2001). In 1996, it was present from September. As the MD of the newly hatched individuals sampled in this study measured about $0.3 \mathrm{~mm}$, the $V$. piscinalis of the late cohort with an MD ranging from 1.88 to $2.52 \mathrm{~mm}$ were probably aged at least 1 to 2 months when they appeared in September 1997 and in October and November from 1998 to 2001. From 1997 to 1999 the late cohort was represented by only a small number of individuals and sometimes disappeared after one or two months (1998 and 1999), most often during flood periods. In May 1997, June 2001 and as early as February 2004, it was no longer possible to distinguish the two cohorts. On the contrary, the early and late cohorts born in 2001 and 2002 remained distinct throughout their lifetimes and represented respectively 2679 vs 465 ind $\mathrm{m}^{-2}$ for the first year and 7503 vs 2576 ind $\mathrm{m}^{-2}$ for the second. The late cohorts $(\mathrm{C} 01 \mathrm{~L}$ and C02L) disappeared a month later than the early cohorts 

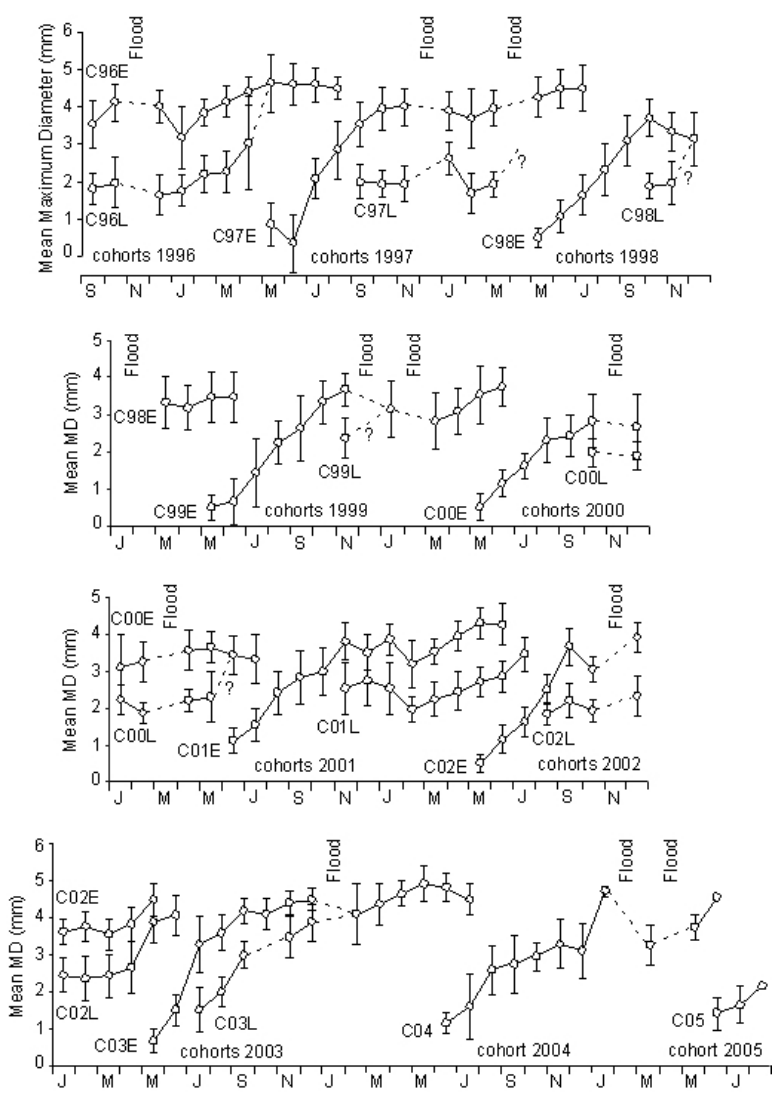

Fig. 5. Mean cohort maximum diameters (open circles) in monthly samples of the Saône river Valvata piscinalis population. Vertical bars are standard deviations. Dotted lines indicate the presumed changes in mean diameters. ( $\mathrm{E}=$ early cohort, $\mathrm{L}=$ late cohort).

(C01E and C02E), respectively in July 2002 and June 2003. The maximum longevity of the late cohort can be estimated at about 12 months. The total density of the two cohorts appearing each year and other life cycle data are given in Table 2.

The number of gravid individuals was usually maximal in May or June (Fig. 6). In 2000, 2002 and 2003 it was particularly high (Table 2). In 1997 and 2003 there were two peaks, one in May and the other in JulyAugust. However, the gravid individuals of the second peak (August 1997 and July 2003) produced very few newborn during the following months: 31 young (with $\mathrm{MD} \leq 2.8 \mathrm{~mm}$ ) in September 1997, 18 and 10 young in August and September 2003, respectively. From 1997 to 1999, gravid individuals were present from February to August. However, from 2000, they were present again in October, then from October 2001 to January
2002, in December 2002, and until December in 2003. On the contrary, in 2004 gravid individuals were not present until August. Eggs were observed from April when macrophytes appeared. The fecundity rate could not be calculated since accurate egg counting was hindered by vegetation.

The mean number of potential reproducers i.e. individuals present between two recruitment periods (generally from October to April) was maximal during 1999-2000, but decreased considerably in 2003-2004 and reached its lowest level in 2004-2005 (Fig 7a). The young/adults ratio of these individuals varied from 0.24 to 1.7 , with the exception of the period 2003-2004, which was characterised by a very high number of adults, when the ratio was only 0.03 (Fig. 7b).

We observed significant inter-annual variations in the mean MD of $V$. piscinalis (early cohort) at the end of summer (September) (ANOVA, $\mathrm{p}<0.01$, Table 2). The mean MD significantly decreased by $1.17 \mathrm{~mm}$ from 1997 to 2000 (Tukey's HSD test, $\mathrm{p}<0.01$ ) then increased by $1.77 \mathrm{~mm}$ from 2000 and 2003 (Tukey's HSD test, $\mathrm{p}<0.01$ ). From 2003 to 2004, the MD decreased by 1.47 $\mathrm{mm}$ (Tukey's HSD test, $\mathrm{p}<0.01$ ) though the largest individual (MD=5.92 mm) was observed in May 2004, which was the result of high growth during the summer of 2003. However inter-annual variability in September size of individuals was not significantly related to temperature during the growth period (May-September, linear regression>0.05). From 1997 to 2004, the mean number of $V$. piscinalis parasitised by digenean trematodes only reached $1.6 \pm 2.1 \%$.

\section{Discussion}

\section{Causes of the phenomena observed ( $P$. amnicum)}

The life cycle data of the $P$. amnicum populations studied clearly show a north-south gradient (Table 3 ). In Canada and Finland the cohort appears later (June-July vs April-May), the maximum number of shelled larvae/ parent is lower (18-29 vs 34-163), the life span is longer (36 vs 15 months) and the clams reach maturity later (12-13 vs 3-4 months) than in countries further south, such as Germany, France, Spain and Portugal (Danneel \& Hinz 1976, Bass 1979, Holopainen 1979, Vincent et al. 1981, Holopainen et al. 1997, Araujo et al. 1999, Sousa et al. 2008). Among the Nordic populations with longer life-spans only that of the St. Lawrence river in Canada produces two cohorts. The highest maximal values of SL and litter size were observed in the rivers furthest south, i.e. the Saône and the Miño (11.66 
Table 2. Life cycle data for Valvata piscinalis in the Saône river (MD= maximum diameter)

\begin{tabular}{|c|c|c|c|c|c|c|c|c|c|c|}
\hline & 1996 & 1997 & 1998 & 1999 & 2000 & 2001 & 2002 & 2003 & 2004 & 2005 \\
\hline Maximum MD (mm) & - & 5.76 & 5.2 & 4.68 & 5.24 & 5.08 & 5.32 & 5.28 & 5.92 & 4.64 \\
\hline $\begin{array}{l}\text { Mean MD }(\mathrm{mm}) \text { in } \\
\text { September (Early cohort) }\end{array}$ & 3.54 & 3.59 & 3.09 & 2.62 & 2.42 & 2.84 & 3.67 & 4.19 & 2.72 & - \\
\hline $\begin{array}{l}\text { Mean temperature } \\
\left({ }^{\circ} \mathrm{C} \text { - May to Sept. }\right)\end{array}$ & 19.7 & 20.4 & 20.3 & 20.2 & 21.7 & 20.6 & 20.9 & 23.8 & 21.7 & - \\
\hline $\begin{array}{l}\text { Minimum MD of gravid) } \\
\text { individual (mm) }\end{array}$ & - & 3.64 & 3.28 & 3.00 & 3.08 & 2.84 & 3.24 & 3.2 & 3.44 & 3.00 \\
\hline $\begin{array}{l}\text { Total number of gravid } \\
\text { individuals }\end{array}$ & - & 256 & 197 & 235 & 484 & 101 & 557 & 609 & 170 & 7 \\
\hline Number of cohorts/year & 2 & 2 & 2 & 2 & 2 & 2 & 2 & 2 & 1 & 1 \\
\hline $\begin{array}{l}\text { Month at which the early } \\
\text { cohort appears }\end{array}$ & - & May & May & May & May & June & May & May & June & June \\
\hline $\begin{array}{l}\text { Month at which the late } \\
\text { cohort appears }\end{array}$ & - & Oct. & Oct. & Nov. & Oct. & Nov. & Aug. & July & - & - \\
\hline \multicolumn{11}{|l|}{ Life-span (month) } \\
\hline - early cohort & $12+$ & 15 & 14 & 14 & 15 & 13 & 13 & 15 & 13 & - \\
\hline - late cohort & $8+$ & $6+$ & $2+$ & $1+$ & $8+$ & 9 & 11 & $7+$ & - & - \\
\hline $\begin{array}{l}\text { Month at which the total } \\
\text { density is maximum }\end{array}$ & - & August & July & August & June & August & June & June & June & July \\
\hline $\begin{array}{l}\text { Total cohort densities } \\
\text { (ind } \mathrm{m}^{-2} \text { ) }\end{array}$ & - & 2638 & 4907 & 4516 & 3506 & 3144 & 10079 & 3870 & 1228 & 32 \\
\hline
\end{tabular}

vs $10-11 \mathrm{~mm}, 163$ vs 73 , respectively) where summer temperatures exceed $25^{\circ} \mathrm{C}$.

Between the periods 1997-1999 and 2000-2002 the following was observed: 1) an increase in the annual mean density (25.4-41.3 vs 68.7-81.5 ind $\mathrm{m}^{-2}$ ) and of the mean size of newborn in April (2.31-2.48 vs 2.57$3.0 \mathrm{~mm}) ; 2$ ) the appearance of gravid individuals as from July and no longer in August; 3 ) a decrease of the minimum mature size (4.48-4.58 vs $2.72-3.4 \mathrm{~mm}$ ) (Fig. $1,2 \& 3$, Table 1). Globally, no relation was observed between the annual mean flow rates and the density of the $P$. amnicum population. Indeed, although the flow rates in 1998 and 2000 were very similar the total densities were very different (320 vs 982 ind $\mathrm{m}^{-2}$ ). Regarding water quality, inter-annual variations in physicochemical properties were low during the whole study period (Mouthon, 2001 and data available at http://rdb. eaurmc.fr). The role of these variables in the life cycle variations and population dynamics of this species in the Saône river is therefore probably limited. On the contrary, the increase of the mean annual temperature by $1.9^{\circ} \mathrm{C}$ between 1998 and 2000 seems to be the most probable cause of the changes observed.

The persistence of small individuals $(\mathrm{SL} \leq 3.5 \mathrm{~mm})$, sometimes several months after the disappearance of gravid individuals i.e. in May and June 2000 (234 and 262 ind. $\mathrm{m}^{-2}$, respectively) and in June 2002 (362 ind. $\mathrm{m}^{-2}$ ) explains the nil or very low growth of cohorts between April and June 2000 and 2002 and the fall in the size of individuals between August and September 2000 (6.28 to $4.88 \mathrm{~mm}$ ) (Fig. 2). These observations as well as the progressive decrease of bivalve size and lit- 


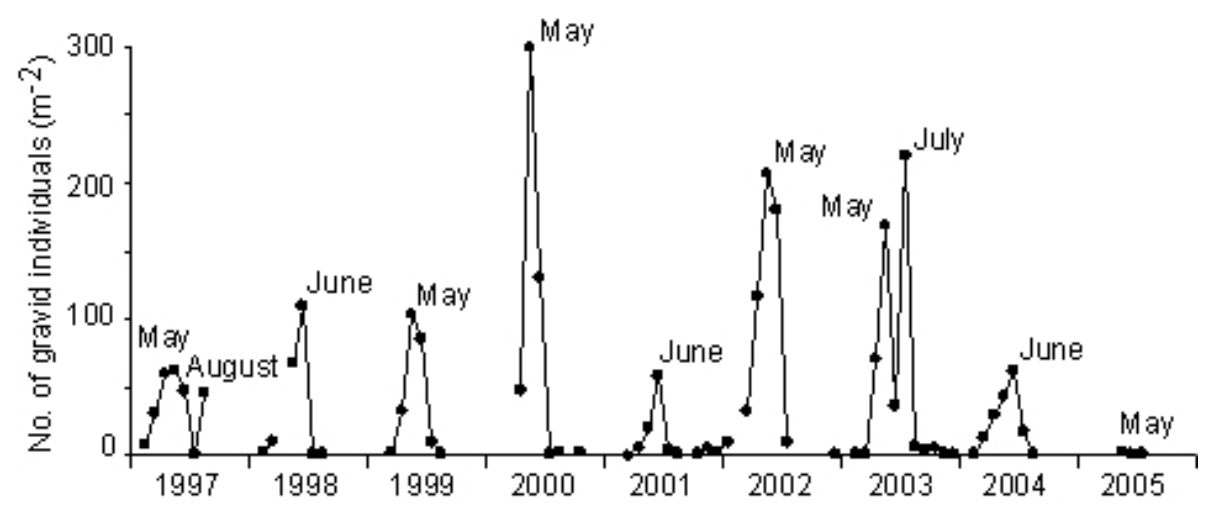

Fig. 6. Seasonal variations in the gravid Valvata piscinalis.
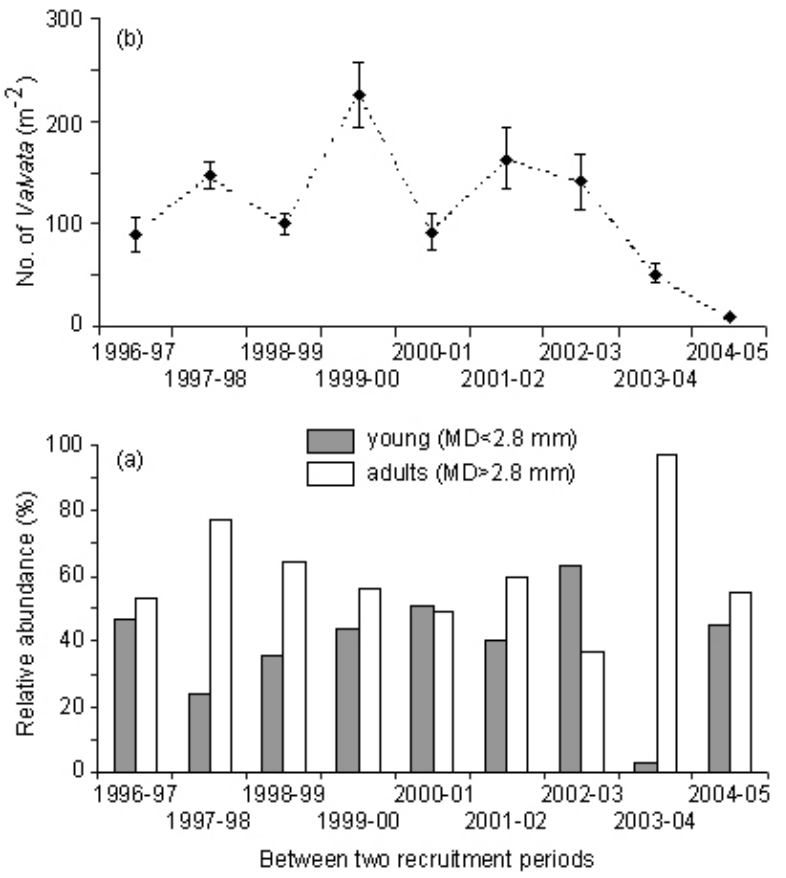

Fig. 7. (a) Mean number $\mathrm{m}^{-2}$ of Valvata piscinalis (potential reproductive individuals) and (b) percentage abundance of young and adults between two recruitment periods. ter size between 1997 and 2002 (Figs 4 a \& b) strongly suggest the possibility of food limitation in these overcrowded situations. In the Saône river resources are clearly limited for several mollusc species (Mouthon 2001, 2004, 2007). Furthermore, the increased rate of parasitism from 2000 (2.0-3.7 vs 6.6-7.7) corroborates the decreased fitness of this population.

In 2003 , summer temperatures reaching $29.5^{\circ} \mathrm{C}$ and exceeding $25^{\circ} \mathrm{C}$ for 75 days vs 0-17 days between 1997 and 2002 (Mouthon \& Daufresne 2006), were responsible for the sudden drop in the population whose density fell from 83 to 2 ind. $\mathrm{m}^{-2}$ between June and August. In the river Minho (Portugal) a rapid decline in mollusc populations, including $P$. amnicum, was also observed during the particularly hot summer 2005 (Sousa et al. 2008).

\section{Causes of the phenomena observed ( $V$. piscinalis)}

Temperature plays a considerable role in the life cycle traits and population dynamics of gastropods (Hunter 1961, 1964, Van der Schalie \& Berry 1973, Vaillancourt \& Couture 1975, Krkač 1979, Costil \& Daguzan 1995, Costil 1997). However, only a few field experiments have been carried out to test the ecological consequences of climatic warming on freshwater macroinvertebrates (Hogg et al. 1995, Hogg \& Williams 1996, McKee et al. 2003) and the latter is alone in taking gastropods into account. The results in this study show that the total density of 6 species (not including $V$. piscinalis) introduced in the microcosm increased significantly with a continuous $3^{\circ} \mathrm{C}$ above ambient and 
Table 3 : Life cycle data for six Pisidium amnicum populations

\begin{tabular}{|c|c|c|c|c|c|c|}
\hline & $\begin{array}{c}\text { Germany } \\
\text { Danneel \& } \\
\text { Hinz (1976) }\end{array}$ & $\begin{array}{c}\text { England } \\
\text { Bass } \\
(1979)\end{array}$ & $\begin{array}{c}\text { Finland } \\
\text { Holopainen } \\
\text { et al. (1997) }\end{array}$ & $\begin{array}{c}\text { Canada } \\
\text { Vincent et al. } \\
(1981)\end{array}$ & $\begin{array}{c}\text { Spain } \\
\text { Araujo et al. } \\
(1999)\end{array}$ & $\begin{array}{c}\text { France } \\
1997-2002 \\
\text { This study }\end{array}$ \\
\hline $\begin{array}{l}\text { Maximum shell length } \\
(\mathrm{mm})\end{array}$ & 8.9 & 9 & 9.3 & 9 & $10-11$ & $10.4-11.66$ \\
\hline $\begin{array}{l}\text { Minimum mature size } \\
(\mathrm{mm})\end{array}$ & 3 & 4 & 3.7 & 4 & $3-4$ & $2.72-5.66$ \\
\hline Age at maturity & $3-5$ & 5 & 13 & 12 & $4-5$ & $4-5$ \\
\hline $\begin{array}{l}\text { Month at which the } \\
\text { cohort appears }^{(1)}\end{array}$ & May-June & May & June-July & June-July & April-May & April \\
\hline $\begin{array}{l}\text { Maximum length } \\
\text { of larvae }(\mathrm{mm})\end{array}$ & 2 & 1.4 & 2.1 & $?$ & 2.4 & 2.36 \\
\hline Number of cohort/parent & 1 & 1 & 1 & 2 & 1 & 1 \\
\hline \multicolumn{7}{|l|}{ Litter size } \\
\hline - mean & $5-8$ & 13 & 12 & 9.2 & no data & $20.2-44$ \\
\hline - maximum & 34 & 37 & 29 & 18 & 73 & 163 \\
\hline Life-span (month) & $12+$ & $12+$ & $36+$ & 36 & 15 & $16-18$ \\
\hline
\end{tabular}

$3^{\circ} \mathrm{C}$ during summer only (McKee et al. 2003). In three Polish reservoirs heated by power plants, the abundance of two non-native species Physella acuta (Draparnaud) and Potamopyrgus antipodarum (Gray) increased during the period 1971-1991. Conversely, V. piscinalis progressively disappeared from these lakes although the maximum temperature of two of them hardly exceeded $25^{\circ} \mathrm{C}$ (Strzelec 1997-1998). Furthermore, Burgmer et al. (2007) observed a decrease in the density and frequency of occurrence of $V$. piscinalis in the Swedish lakes with increasing temperatures between 1988 and 2003.

In the Saône river $V$. piscinalis appeared to tolerate warmer water until 2003: 1) a high number of gravid individuals in 2000, 2002 and 2003; 2) a peak density in 2002 in spite of a fall in numbers in 2001, the consequence of potential/possible competition with Lithoglyphus naticoides (Fig 1 - Mouthon 2007); 3) a mean density in 2003 close to those from 1998 to 2000 ; 4) an increase of mean MD in September from 2000 to 2003, i.e. during the warmest years (Table 2). Furthermore, the substantial fall of MD from 1997 to
$1999(0.97 \mathrm{~mm})$ cannot be explained by temperature, since it only varied by $0.2^{\circ} \mathrm{C}$ during the growth period throughout these three years, but perhaps by a lack of available resources. The appearance of gravid individuals in autumn and winter during the hottest years and particularly in 2001 and 2003, which produced very few newborn, expresses either physiological plasticity or a disruption in the reproductive physiology of V. piscinalis.

From 2004 a major change in the biological characteristics of the population was observed: 1 ) density fell dramatically; 2) the number of cohorts per year fell from 2 to $1 ; 3$ ) the later appearance (June vs May) of the early cohort; 4) the potential reproducers before the spawning period in 2004 were mainly composed by adults $(\mathrm{MD}>2.8 \mathrm{~mm})$. A wide range of sizes among individuals before the reproduction period led to a longer spawning period and favoured the production of a second cohort. However, in spring 2004, only the adults were represented and the spawning period, which was shorter, only led to a single cohort. Since the density of 
these adults was low (Fig 7a), the numbers of the 2004 cohort were the smallest observed since 1997 (Table 2). Between October 2004 and April 2005 the young/adults ratio returned to greater equilibrium $(0.81)$ although the low number of potential reproducers $\left(9.5\right.$ ind. $\left.\mathrm{m}^{-2}\right)$ did not permit the population to reach its former level. Consequently the 2003 heatwave appeared to be the main cause for the decline of the population of $V$. piscinalis.

The difference in tolerance to the heatwave observed between $P$. amnicum and $V$. piscinalis is in agreement with the preference of these two species in rivers (medium rhithron and lower rhithron-potamon, respectively - Mouthon 1999). Regarding the temperature-size rule, a reduction in the size of these two species in relation to the increase of temperature in the Saône river cannot be observed: competition for resources and/or stressful temperature are possible explanations (Atkinson 1995).

\section{Recovery possibilities}

The reproductive potential of Pisidium is quite low (Way \& Wissing 1982). In the Saône river P. amnicum only produces a single cohort a year vs five for Pisidium subtruncatum Malm, (Mouthon 1999). In addition, $P$. amnicum is most often represented in the potamon by only metapopulations whose distance from each other hinders recolonisation. $V$. piscinalis produces two cohorts a year and according to Lodge \& Kelly (1985), possesses good resilience, i.e. adjustment following habitat disturbance. However, its resilience to the 2003 heatwave seemed poor. Indeed in 2004 and 2005 the production of only one cohort was observed although the density of the other molluscs also remained low (Fig 1 c \& d). The critical level of numbers from 2004 (P. amnicum) and in 2005 (V. piscinalis), with intra and interspecific competition for limited resources, the major decrease of donor patches observed in the middle Saône valley and in the lower reaches of its main tributaries, the Doubs and the Ognon (Mouthon \& Daufresne 2006), and the appearance in July 2002 of another potential competitor Hypania invalida, an active filter feeding and deposit feeder polychaete (Manoleli 1975), have considerably reduced the capacities for recovery of these two species.

Since inter-annual variations in physicochemical properties were low throughout the study period (Mouthon, 2001 and data available at http://rdb.eaurmc.fr) the observations carried out strongly suggest that the insufficiency of available food is one of the possible causes for their lack of recovery in the Saône river upstream of Lyon. A decrease in the resilience of macroinvertebrate communities affected by extreme hydroclimatic events was also observed in the Rhône river (Daufresne et al. 2007). On a wider scale, increases of mean temperature and the frequency of heatwaves during the century predicted by different models (Beniston \& Diaz 2004, EEA 2004, Schär et al. 2004, Meehl \& Tebaldi 2004) could result in the gradual disappearance of $P$. amnicum from the potamon and of $V$. piscinalis from the freshwater systems most directly exposed to climatic warming (Webb 1996), such as the Saône River.

\section{References}

Atkinson D. 1995. - Effects of temperature on the size of aquatic ectotherms: exceptions to the general rule. J. Therm Biol., 20, 61-74.

Araujo R., Ramos M.A. \& Molinet R. 1999. - Growth pattern and dynamics of a southern peripheral population of Pisidium amnicum (Müller, 1774) (Bivalvia: Sphaeriidae) in Spain. Malacologia, 41, 119-137.

Bass J.A.B. 1979. - Growth and fecundity of Pisidium amnicum (Müller) (Bivalvia: Sphaeriidae) in the Tadnoll Brook, Dorset, England. J. Conch., 30, 129-134.

Bhattacharya C.G. 1967. - A simple method of resolution of a distribution into Gaussian components. Biometrics, 23, 115-135.

Beniston M. \& Diaz H. 2004. - The 2003 heatwave as an example of summers in a greenhouse climate? Observations and climate model simulations for Basel, Switzerland. Global and Planetary Change, 44, 73-81.

Black E., Blackburn M., Harrison G., Hoskins B. \& Methven J. 2004. - Factors contributing to the summer 2003 European heatwave. Weather, 59, 217-223.

Burgmer T., Hillebrand H. \& Pfenninger M. 2007. - Effects of climate-driven temperature changes on the diversity of freshwater macroinvertebrates. Oecologia, 151, 93-103.

Bradley D.C. \& Ormerod S.J. 2001. - Community persistence among stream invertebrates tracks the North Atlantic Oscillation. J. Anim. Ecol., 70, 987-996.

Cleland D.M. 1954. - A study of the habits of Valvata piscinalis (Müller) and the structure and function of the alimentary canal and reproductive system. Proc. Malac. Soc. Lond., 30, 167-203.

Costil K. \& Daguzan, J. 1995. - Effect of temperature on reproduction in Planorbarius corneus (L.) and Planorbis planorbis (L.). Malacologia, 36, 79-89.

Danneel I. \& Hinz W. - 1976. Zur Biologie von Pisidium amnicum (O.F. Müller) (Bivalvia). Arch. Hydrobiol., 77, 213-225.

Daufresne M., Roger M.C., Capra H. \& Lamouroux N. 2004. - Longterm changes within the invertebrate and fish communities of the Upper Rhône River: effects of climatic factors. Global Change Biology, 10, 124-140.

Daufresne M., Bady P. \& Fruget J.F. 2007. - Impacts of global changes and extreme hydroclimatic events on macroinvertebrate community structure in the French Rhône River. Oecologia, 151, 544-559.

EEA 2004. - Impact of Europe changing climate. An indicator-based assessment. - Copenhagen, Danemark, Report $\mathrm{N}^{\circ} 2,107$ pp.

Fretter V. \& Graham A. 1978. - The Prosobranch molluscs of Britain and Danemark. Part 3- Neritacea, Viviparacea, Valvatacea, terrestrial and freshwater Littorinacea and Rissoacea. J. Mollusc Stud., Suppl., 5, 101-152.

Frömming E. 1956. - Biologie der mitteleuropäischen Süsswasser- 
schnecken. Duncker \& Humblot, Berlin, 311 pp.

Gayanilo F.C., Sparre P. \& D. Pauly, D. 1996. - FAO-ICLARM stock assessment tools. Food and Agriculture Organization of the United Nations, Rome. Computed information series 8, 126 pp.

Heard W.H. 1965. - Comparative life histories of North American pill clams (Sphaeriidae: Pisidium). Malacologia, 2, 381-411.

Hogg I.D., Williams D.D., Eadie J.M. \& Butt S.A. 1995. - The consequence of global warming for stream invertebrates: a field simulation. J. therm. Biol., 20, 199-206.

Hogg I.D. \& Williams D.D. 1996. - Response of stream invertebrates to a global-warming thermal regime: an ecosystem-level manipulation. Ecology, 77, 395-407.

Holopainen I.J. 1979. - Population dynamics and production of Pisidium species (Bivalvia, Sphaeriidae) in a oligotrophic and mesohumic lake Pääjärvi, southern Finland. Arch. Hydrobiol., Suppl., 4, 466-508.

Holopainen I.J., Lamberg S., Valtonen E.T. \& Rantanen J. 1997. - Effects of parasites on life history of the freshwater bivalve, Pisidium amnicum, in Eastern Finland. Arch. Hydrobiol., 139, 461-477.

Hunter R.W. 1961. - Life cycle of four freshwater snails in limited populations in Loch Lomond, with a discussion of infraspecific variation. Proc. Zool. Soc. Lond., 137, 135-171.

Hunter R.W. 1964. - Physiological aspects of ecology in non marine molluscs. - In: Wilbur K.M. \& Younge C.M. (eds): Physiology of Mollusca. vol. 1. - Academic Press, N.Y. \& London, 83-126 pp.

Krkač N. 1979. - Temperature and reproductive cycle relations in Radix peregra O.F. Müller. Malacologia, 18, 227-232.

Lodge D.M. \& Kelly P.1985. - Habitat disturbance and the stability of freshwater gastropod population. Oecologia (Berlin), 68, 111-117.

Lopez G.R. \& Holopainen I.J. 1987. - Interstitial suspension-feeding by Pisidium spp. (Pisidiidae: Bivalvia): a new guild in the lentic benthos? Am. Malac. Bull., 5, 21-30.

Luterbacher J., Dietrich D., Xoplaki E., Grosjean M. \& Wanner H. 2004. - European seasonal and annual temperature variability, trends, and extremes since 1500. Science, 303, 1499-1503.

Mackie G.L. 1978. - Are sphaeriid clams ovoviviparous or viviparous? The Nautilus, 92, 145-147.

McKee D., Atkinson D., Collings S.E., Eaton J.W., Gill A.B., Harvey I., Hatton K., Heyes T., Wilson D. \& Moss B. 2003. - Response of freshwater microcosm communities to nutrients, fish, and elevated temperature during winter and summer. Limnol. Oceanogr., 48, 707-722.

Meier-Brook C. 1970. - Untersuchungen zur Biologie einiger Pisidium-Arten (Mollusca; Eulamellibranchiata; Sphaeriidae). Arch. Hydrobiol. Suppl., 38, 73-150.

Meier-Brook C. 1977.- Intramarsupial suppression of fetal development in Sphaeriid clams. Malacol. Rev., 10, 53-58.

Manoleli D. 1975. - On the distribution, biology and origin of Polychaeta from the Danube and the Danube Delta. Trav. Mus. Hist. Nat. Grigore Antipa, 21, 131-138.

Meehl G.A. \& Tebaldi C. 2004. - More intense, more frequent, and longer lasting heat waves in the $21^{\text {st }}$ century. Science, 305, 994997.

Mouthon J. 1996. - Molluscs and biodegradable pollution in rivers: proposal for a scale of sensitivity of species. Hydrobiologia, 317 221-229.

Mouthon J. 1999. - Longitudinal organisation of the mollusc species in a theoretical French river. Hydrobiologia, 390, 117-128.

Mouthon J. 2001. - Life cycle and population dynamics of the Asiatic clam Corbicula fluminea (Bivalvia: Corbiculidae) in Saône River at Lyon (France). Hydrobiologia, 452, 109-119.

Mouthon J. 2004. - Life cycle of Musculium lacustre (Bivalvia: Sphaeriidae) in the Saône river at Lyon: a curious life strategy. Ann. Limnol.- Int. J. Lim., 40, 279-284.

Mouthon J. 2005. - Life cycle and population dynamics of Pisidium subtruncatum Malm (Bivalvia: Sphaeriidae) in the Saône, a large lowland river, at Lyon (France): environmental influences. Arch. Hydrobiol., 163, 539-554.

Mouthon J. 2007. - Lithoglyphus naticoides (Pfeiffer) (Gastropoda: Prosobranchia): distribution in France, population dynamics and life cycle in the Saône river at Lyon (France). Ann. Limnol.- Int. J. Lim., 43, 53-59.

Mouthon J. \& Daufresne M. 2006. - Effects of the 2003 heatwave and climatic warming on mollusc communities of the Saône: a large lowland river and its two main tributaries (France). Global Change Biology, 11, 1-9.

Nekrassov A.D. 1929. - Vergleichende Morphologie der Laiche von Süsswassergastropoden. Z. Morph. Okol. Tiere, 13, 1-35.

Odhner N.H. 1929. - Die Molluskenfauna des Täkern. Sjon Täkerns Fauna och Flora, 8, 1-129.

Schär C., Vidale P.L., Lüthi D., Frei C., Häberli C., Liniger M.A. \& Appenzeller C. 2004. - The role of increasing temperature variability in European summer heatwaves. Nature, 427, 332-336.

Sousa R., Nogueira A.J.A., Antunes C. \& Guilhermo L. 2008.- Growth and production of Pisidium amnicum in the freshwater tidal area of the River Minho estuary. Estuar. Coast. Shelf S., 79, 467-474.

Stenseth N.C., Mysterud A., Ottersen G., Hurrell J.W., Chan K.S. \& Lima M. 2002. - Ecological effects of climate fluctuations. Science, 297, 1292-1296.

Strzelec M. 1997-1998. - Effect of thermal discharges from a power plant on the freshwater snail fauna in three polish lakes. Walkerana, 9, 139-150.

Thomas G.J. 1959. - Self-fertilization and production of young in a sphaeriid clam. The Nautilus, 72, 131-140.

Tsikhon-Lukanina E.A. 1963. - On the problem of the filtration feeding method of Bithynia tentaculata L. and Valvata piscinalis Müller. Byull. Inst. Biol. Vodokhr., 10, 28-30.

Vaillancourt G. \& Couture R. 1975. - Effets des variations de la température de l'eau sur quelques espèces de Physidae, Lymnaeidae, Planorbidae et hydrobiidae (Gastropoda). Sterkiana, 57, 18-32.

Van der Schalie H. \& Berry E.G. 1973. - The effects of temperature on growth and reproduction of aquatic snails. Sterkiana, 50, 1-92.

Vincent B., Vaillancourt G. \& Lafontaine N. 1981. - Cycle de développement, croissance et production de Pisidium amnicum (Müller) (Mollusca : Bivalvia) dans le Saint-Laurent (Quebec). Can. J. Zool., 59, 2350-2359.

Walther G.R., Post E., Convey P., Menzel A., Parmesan C., Beebee T.J., Fromentin J.M., Hoegh-Guldberg O. \& Bairlein F. 2002. Ecological responses to recent climate change. Nature, 416, 389395.

Webb B.W. 1996. - Trends in stream and river temperature. Hydrol. Process., 10, 205-226.

Young M. R. 1975. - The life cycle of six species of freshwater molluscs in the Worcester-Birmingham canal. Proc. Malac. Soc. Lond., 41, 533-548. 
